\title{
Asticcacaulis taihuensis sp. nov., a novel stalked bacterium isolated from Taihu Lake, China
}

\author{
Zhi-Pei Liu, Bao-Jun Wang, Shuang-Jiang Liu and Ying-Hao Liu
}

Correspondence

Shuang-Jiang Liu

shuangjiang@hotmail.com
State Key Laboratory of Microbial Resource at the Institute of Microbiology, Chinese Academy of Sciences, ZhongGuanCun, Haidian, Beijing 100080, People's Republic of China
The genus Asticcacaulis was established by Poindexter (1964) to accommodate isolates that were regarded as representing Caulobacter species but with prosthecae that were not adhesive. Subsequent studies on 16S rRNA gene sequence similarities and chemotaxonomic features indicated that members of the genus Asticcacaulis were distantly related to members of the genera Caulobacter and Brevundimonas (Abraham et al., 2001; Sly et al., 1999). Asticcacaulis comprises only two species (Poindexter, 1989), Asticcacaulis excentricus Poindexter 1964 and Asticcacaulis biprosthecium Pate et al. 1973. All strains representative of this genus have been isolated from freshwater environments.

During ecological surveys on the freshwater Taihu Lake

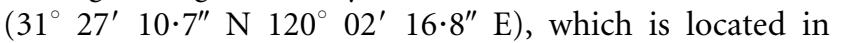
Jiangsu Province, China, strain $\mathrm{T} 3-\mathrm{B} 7^{\mathrm{T}}$ was isolated from lake sediment by plating 10 -fold dilutions of samples on diluted $\mathrm{LB}$ agar $(0.5 \mathrm{~g}$ yeast extract, $1 \mathrm{~g}$ peptone, $1 \mathrm{~g} \mathrm{NaCl}$, $15 \mathrm{~g}$ Difco agar, 1 litre distilled water). Sediment samples were obtained from $10 \mathrm{~cm}$ beneath the sediment surface. Routine cultivation was conducted with LB agar or LB broth at $30^{\circ} \mathrm{C}$.

Published online ahead of print on 7 January 2005 as DOI 10.1099/ ijs.0.63334-0.

The GenBank/EMBL/DDBJ accession number for the 16S rRNA gene sequence of strain T3-B7 ${ }^{\top}$ is $A Y 500141$.

Polar lipid profiles of $A$. taihuensis T3-B7 ${ }^{\top}$ and $A$. biprosthecium DSM $4723^{\top}$ are shown in a supplementary figure available in IJSEM Online.
Gram reactions were determined by staining cells grown on LB agar at $30^{\circ} \mathrm{C}$ for $24 \mathrm{~h}$ according to the method described by Gerhardt et al. (1994). Endospore formation was determined after malachite green staining of cells grown on LB agar. Flagellation and stalk generation were examined by transmission electron microscopy (H-600; Hitachi) at $100 \mathrm{kV}$ after negative staining with $1 \%(\mathrm{w} / \mathrm{v})$ phosphotungstic acid. Denitrification capacity was determined by the method of Stanier et al. (1966). For assimilation of carbon sources, the standard mineral base of Stanier et al. (1966) was used. After the mineral base was autoclaved, each compound was added at a concentration of $0.2 \%(\mathrm{w} / \mathrm{v})$. Growth was examined after incubation at $30{ }^{\circ} \mathrm{C}$ for $1,3,7$ and 14 days. Aerobic and anaerobic production of acids (OF reaction) from carbohydrates was determined in OF basal medium (Hugh \& Leifson, 1953). Carbohydrate solution sterilized by filtration was added at a concentration of $1 \%(\mathrm{w} / \mathrm{v})$, and acid production was recorded after 7 and 14 days of incubation. Cellular fatty acids were extracted and analysed by using the Sherlock system (MIDI Inc.) following the recommendations of the manufacturer. Polar lipids were separated with one- and two-dimensional TLC and were characterized with spreading reagents specific for $\alpha$-glycols (periodate-Schiff), sugars ( $\alpha$-naphthol- $\mathrm{H}_{2} \mathrm{SO}_{4}, \quad$ anisaldehyde- $\mathrm{H}_{2} \mathrm{SO}_{4}$ ), phosphate (Zindzadze), free amino groups (ninhydrin) and quaternary nitrogen compounds (Dragendorff) (Ventosa et al., 1993). The developed spots were identified by comparison with those of A. biprosthecium DSM $4723^{\mathrm{T}}$. 

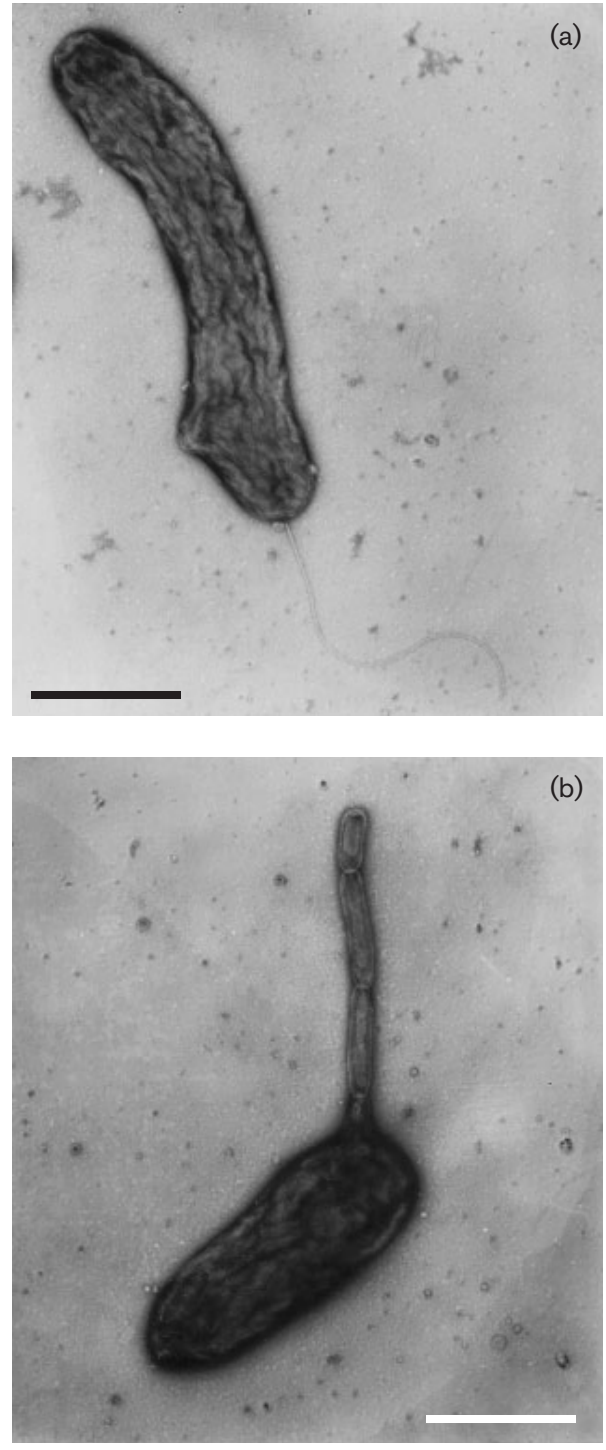

Fig. 1. Transmission electron micrographs of cells of strain T3$B 7^{\top}$ showing a single polar flagellum (a) and the typical stalk near the cell pole (b). Bars, $1 \mu \mathrm{m}$.
DNA base composition was determined by thermal denaturation (Marmur \& Doty, 1962) using DNA from Escherichia coli DH- $5 \alpha$ as a control. DNA-DNA hybridizations were carried out according to the method of De Ley et al. (1970). Renaturation rates and levels of relatedness were calculated as described by Jahnke (1992). 16S rRNA genes were amplified and sequenced as described by Zhang et al. (2003), and 16S rRNA gene sequence alignments were performed with the CLUSTAL $\mathrm{X}$ program (version 1.64b; Thompson et al., 1997). A phylogenetic tree was constructed by the neighbour-joining method (Saitou \& Nei, 1987) with Kimura's two-parameter calculation model in TREECON $\mathrm{W}$ version $1.3 \mathrm{~b}$.

Cells of strain $\mathrm{T} 3-\mathrm{B} 7^{\mathrm{T}}$ are Gram-negative, aerobic, nonspore-forming rods. They are motile with a single polar flagellum (Fig. 1a). A single stalk was located near the cell pole and the stalk possessed no adhesive material (Fig. 1b). 16S rRNA gene sequence analysis indicated that strain T3$B 7^{\mathrm{T}}$ was phylogenetically related to members of the genus Asticcacaulis, with similarities of $95.0 \%$ to A. excentricus DSM $4724^{\mathrm{T}}$ and $98.5 \%$ to A. biprosthecium DSM $4723^{\mathrm{T}}$. Based on these 16S rRNA gene sequence analyses, a neighbour-joining tree was constructed (Fig. 2); the results showed that strain $\mathrm{T} 3-\mathrm{B}^{\mathrm{T}}$ and the two recognized species of the genus Asticcacaulis were grouped together to form a cluster with $100 \%$ bootstrap support. Investigation of polar lipids revealed that strain $\mathrm{T} 3-\mathrm{B} 7^{\mathrm{T}}$ contained phosphatidylglycerol, 1,2-diacyl-3-O- $\alpha$-D-glucopyranosyl glycerol, 1,2-diacyl-3-O- $\alpha$-D-glucuronopyranosyl glycerol and three unidentified phospholipids (see Supplementary Fig. A in IJSEM Online). Comparison with A. biprosthecium DSM $4723^{\mathrm{T}}$ reported by Abraham et al. (2001) showed that both strains contained phosphatidylglycerol, 1,2-diacyl-3$O-\alpha$-D-glucopyranosyl glycerol and 1,2-diacyl-3-O- $\alpha$-Dglucuronopyranosyl glycerol, but that the two strains differed in their unidentified polar lipids (compare Supplementary Figs A and B). Strain $\mathrm{T} 3-\mathrm{B}^{\mathrm{T}}$ also differed from $A$. excentricus and $A$. biprosthecium with regard to the number and position of its stalks, assimilation of sugars (L-arabinose, D-mannose, D-ribose and sucrose), tolerance to $\mathrm{NaCl}$ and nitrite reduction (Table 1). Cellular fatty acid

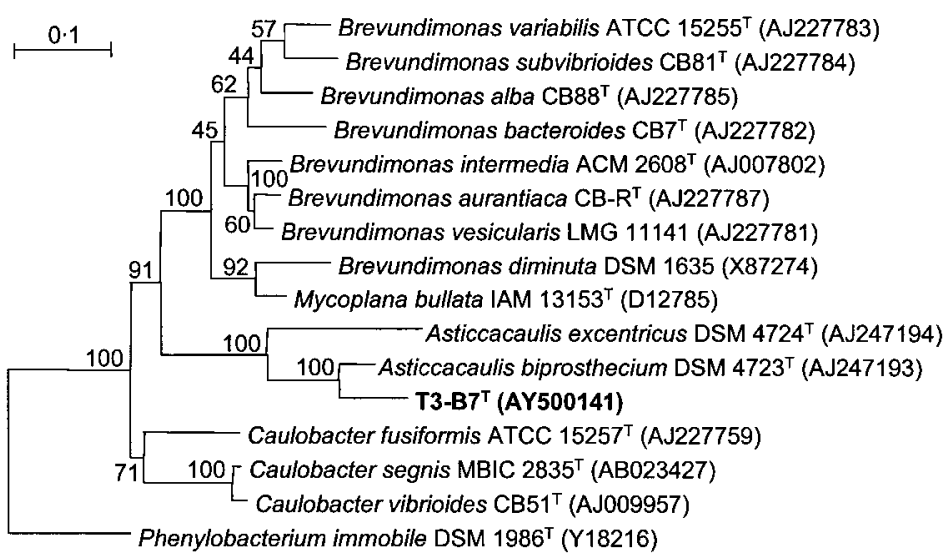

Fig. 2. Phylogenetic tree constructed with the neighbour-joining method based on $16 \mathrm{~S}$ rRNA gene sequence analysis of strain T3-B7 ${ }^{\top}$ and related bacteria. Numbers at nodes indicate percentages of bootstrap support based on 1000 resampled datasets. Phenylobacterium immobile was used as the outgroup. Bar, evolutionary distance $\left(K_{\text {nuc }}\right)$ of $0 \cdot 1$. 
Table 1. Characteristics used to differentiate strain $\mathrm{T} 3-\mathrm{B} 7^{\top}$ from other Asticcacaulis species

+, Positive; -, negative; D, 11-89\% of strains positive. Data for reference species were taken from Poindexter (1989) unless stated.

\begin{tabular}{|lccc|}
\hline Characteristic & T3-B7 $^{\mathbf{T}}$ & A. excentricus & A. biprosthecium \\
\hline Assimilation of: & & & - \\
L-Arabinose & + & $\mathrm{D}$ & - \\
D-Mannose & + & + & - \\
Sucrose & + & + & - \\
Growth on NaCl at: & & + & - \\
$10 \mathrm{~g} \mathrm{l}^{-1}$ & + & + & 2 \\
$25 \mathrm{~g} \mathrm{l}^{-1}$ & - & $\mathrm{D}$ & Lateral \\
Nitrate reduction & + & 1 & \\
Number of prosthecae & 1 & Subpolar & \\
Position of prosthecae & Subpolar & & \\
\end{tabular}

${ }^{\star}$ Data for A. excentricus and A. biprosthecium were taken from Abraham et al. (2001).

profiles of strains $\mathrm{T} 3-\mathrm{B} 7^{\mathrm{T}}$, A. biprosthecium DSM $4723^{\mathrm{T}}$ and A. excentricus DSM $4724^{\mathrm{T}}$ are given in Table 2. Levels of DNA-DNA relatedness of strain $\mathrm{T} 3-\mathrm{B}^{\mathrm{T}}$ to $A$. excentricus DSM $4724^{\mathrm{T}}$ and A. biprosthecium DSM $4723^{\mathrm{T}}$ were $18 \cdot 0$ and $37 \cdot 1 \%$, respectively. Based on the above results we conclude that strain $\mathrm{T} 3-\mathrm{B} 7^{\mathrm{T}}$ represents a novel species of the genus

Table 2. Cellular fatty acid compositions of strain T3-B $7^{\top}$ and the type strains of Asticcacaulis species

Only fatty acids accounting for more than $1.0 \%$ in one of the strains studied are indicated. -, Not detected. Data for reference species were taken from Abraham et al. (2001).

\begin{tabular}{|lccc|}
\hline Fatty acid & T3-B $^{\text {T }}$ & A. excentricus & A. biprosthecium \\
\hline $12: 0$ & - & - & $2 \cdot 5$ \\
$12: 0$ 3-OH & $2 \cdot 32$ & - & - \\
$12: 1$ 3-OH & $2 \cdot 61$ & $4 \cdot 2$ & $7 \cdot 5$ \\
$14: 0$ & $1 \cdot 08$ & - & $1 \cdot 1$ \\
$15: 0$ & $1 \cdot 53$ & $2 \cdot 3$ & $2 \cdot 9$ \\
anteiso-15:0 & $2 \cdot 58$ & - & - \\
$16: 0$ & $28 \cdot 69$ & $17 \cdot 3$ & $20 \cdot 8$ \\
$16: 0$ 2-OH & $10 \cdot 4$ & - & - \\
Summed feature $44^{*}$ & $7 \cdot 41$ & $7 \cdot 4$ & $13 \cdot 8$ \\
iso-16:0 & - & $1 \cdot 8$ & - \\
$17: 0$ & - & $1 \cdot 8$ & - \\
$17: 1 \omega 6 c$ & - & $1 \cdot 5$ & $1 \cdot 0$ \\
$17: 1 \omega 8 c$ & - & $1 \cdot 1$ & - \\
Summed feature $7^{*}$ & $41 \cdot 86$ & $57 \cdot 7$ & $40 \cdot 7$ \\
cyclo $19: 0 \omega 8 c$ & $1 \cdot 46$ & - & - \\
& & & \\
\hline
\end{tabular}

${ }^{\star}$ Summed features consist of one or more fatty acids that could not be separated. Summed feature 4 contained iso-15:0 $2 \mathrm{OH}, 16: 1 \omega 7 c$ and/or $16: 1 \omega 7 t$; summed feature 7 consisted of $18: 1 \omega 7 c, 18: 1 \omega 9 t$ and/or $18: 1 \omega 12 t$.
Asticcacaulis, for which the name Asticcacaulis taihuensis is proposed.

\section{Description of Asticcacaulis taihuensis sp. nov.}

Asticcacaulis taihuensis (tai.hu.en'sis. N.L. masc. adj. taihuensis pertaining to Taihu Lake, the source of the sediment from which the type strain was isolated).

Gram-negative, aerobic, non-spore-forming rods. Motile with a single polar flagellum. Forms a single typical stalk near its cell pole and the stalk possesses no adhesive material. Assimilates L-arabinose, D-cellobiose, D-fructose, D-galactose, D-glucose, D-mannose, D-maltose, D-melibiose, raffinose, L-rhamnose, lactose, sucrose, D-trehalose, Dxylose, melezitose, L-alanine and L-proline but not Dribose, D-mannitol, D-sorbitol, $\beta$-alanine, L-arginine, L-phenylalanine, L-lysine or citrate. Acids are produced oxidatively from L-arabinose, D-fructose, D-galactose, Dglucose, D-mannose, D-maltose, L-rhamnose, lactose, Dxylose and melezitose but not from raffinose, D-ribose, sucrose, trehalose, D-mannitol or D-sorbitol. Cells grow well at $\mathrm{NaCl}$ concentrations below $20 \mathrm{~g} \mathrm{l}^{-1}$. Starch and aesculin are hydrolysed, but gelatin is not. Nitrate is reduced to nitrite. Does not denitrify. Arginine dihydrolase and urease are negative. Major cellular fatty acids are octadecanoic acid $(18: 1)$, hexadecanoic acid $(16: 0)$, 2hydroxy-hexadecanoic acid $(16: 02-\mathrm{OH})$ and hexadecanoic acid (16:1). Contains phosphatidylglycerol, 1,2-diacyl3 -O- $\alpha$-D-glucopyranosyl glycerol, 1,2-diacyl-3-O- $\alpha$-Dglucuronopyranosyl glycerol and three unidentified phospholipids. The $\mathrm{G}+\mathrm{C}$ content of the DNA is $59 \mathrm{~mol} \%\left(T_{\mathrm{m}}\right)$.

The type strain, $\mathrm{T} 3-\mathrm{B} 7^{\mathrm{T}}\left(=\mathrm{AS} 1.3431^{\mathrm{T}}=\mathrm{JCM} 12463^{\mathrm{T}}\right)$, was isolated from sediment of Taihu Lake, Jiangsu Province, China. 


\section{Acknowledgements}

This work was supported by grants from the Chinese Academy of Sciences (KJCX1-SW-12-II-02-02) and from the Natural Science Foundation of China (20177034).

\section{References}

Abraham, W.-R., Strömpl, C., Vancanneyt, M., Lünsdorf, H. \& Moore, E. R. B. (2001). Determination of the systematic position of the genus Asticcacaulis Poindexter by a polyphasic analysis. Int J Syst Evol Microbiol 51, 27-34.

De Ley, J., Cattoir, H. \& Reynaerts, A. (1970). The quantitative measurement of DNA hybridization from renaturation rates. Eur J Biochem 12, 133-142.

Gerhardt, P., Murray, R. G. E., Wood, W. A. \& Krieg, N. R. (1994). Methods for General and Molecular Bacteriology. Washington, DC: American Society for Microbiology.

Hugh, R. \& Leifson, E. (1953). The taxonomic significance of fermentative versus oxidative metabolism of carbohydrates by various gram negative bacteria. J Bacteriol 66, 24-26.

Jahnke, K.-D. (1992). BASIC computer program for evaluation of spectroscopic DNA renaturation data from Gilford System 2600 spectrophotometer on a PC/XT/AT type personal computer. J Microbiol Methods 15, 61-73.

Marmur, J. \& Doty, P. (1962). Determination of the base composition of deoxyribonucleic acid from its thermal denaturation temperature. J Mol Biol 5, 109-118.
Pate, J. L., Porter, J. S. \& Jordan, T. L. (1973). Asticcacaulis biprosthecum sp. nov. Life cycle, morphology and cultural characteristics. Antonie van Leeuwenhoek 39, 569-583.

Poindexter, J. S. (1964). Biological properties and classification of the Caulobacter group. Bacteriol Rev 28, 231-295.

Poindexter, J. S. (1989). Genus Asticcacaulis Poindexter 1964, $282^{\mathrm{AL}}$. In Bergey's Manual of Systematic Bacteriology, vol. 3, pp. 1939-1942. Edited by J. T. Staley, M. P. Bryant, N. Pfennig \& J. G. Holt. Baltimore: Williams \& Wilkins.

Saitou, N. \& Nei, M. (1987). The neighbor-joining method: a new method for reconstructing phylogenetic trees. Mol Biol Evol 4, 406-425.

Sly, L. I., Cox, T. L. \& Beckenham, T. B. (1999). The phylogenetic relationships of Caulobacter, Asticcacaulis and Brevundimonas species and their taxonomic implications. Int J Syst Bacteriol 49, 483-488.

Stanier, R. Y., Palleroni, N. J. \& Doudoroff, M. (1966). The aerobic pseudomonads: a taxonomic study. J Gen Microbiol 43, 159-271.

Thompson, J. D., Gibson, T. J., Plewniak, F., Jeanmougin, F. \& Higgins, D. G. (1997). The CLUSTAL_X Windows interface: flexible strategies for multiple sequence alignment aided by quality analysis tools. Nucleic Acids Res 25, 4876-4882.

Ventosa, A., Marquez, M. C., Kocur, M. \& Tindall, B. (1993). Comparative study of "Micrococcus sp." strains CCM 168 and CCM 1405 and members of the genus Salinicoccus. Int J Syst Bacteriol 43, 245-248.

Zhang, D., Yang, H., Zhang, W., Huang, Z. \& Liu, S.-J. (2003). Rhodocista pekingensis sp. nov., a cyst-forming phototrophic bacterium from a municipal wastewater treatment plant. Int J Syst Evol Microbiol 53, 1111-1114. 